\title{
Enriching Pedagogical Competency of Science Teachers through Simulation Class in Pre Service Teacher Education: An Action Research in College of Teacher Education
}

\author{
Srutirupa Panda ${ }^{1}$

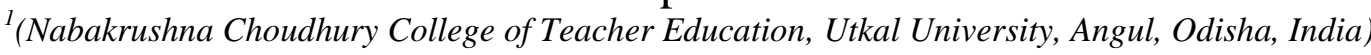

\begin{abstract}
The role of pre service teacher education is crucial for creating skilled science teacher for the society that develops competency to teach science effectively at secondary level. However it is found from various researches that science teachers are unable to express adequate level of pedagogical competency in secondary classroom. This would create tremendous challenges to future science education system. Therefore one action research is carried out to solve the problem of low pedagogical competency of science teacher in college of teacher education. In this concern simulation classes has been implemented. Observation schedule, checklist, interview tools are used to map the pedagogical competency of 40 student science teacher. It is found that there lies significant difference in the scores of pedagogical competency of student science teachers before simulation and during internship program i.e. after simulation. Student teachers have self evaluated through checklist and responded that simulation has improved their pedagogical competency. Faculties have also opined that simulation classes are the effective tool for enriching pedagogical competency of science teachers.

Kew Words: Pre service Teacher Education, Effectiveness, Simulation Class, Action Research
\end{abstract}

\section{Introduction}

Teachers are the dynamic energy for the development and reconstruction of nation as they shoulder responsibility of building future citizens for the society. The place of teacher in current scenario of society is really crucial due to his/her pivotal role in social progress and in the transmission of wisdom, knowledge and experience of one generation to another. In addition to this they also create suitable environment to prepare competent manpower for new innovations and national development by teaching. Teaching is a process which means "causing to learn". Teachers need to create suitable environment and enough competency to make students learn which itself is a challenge for the teacher. To attain this goal a teacher must have adequate knowledge, understanding, skills, attitude and values, lacking which a teacher cannot deliver his/her duty appropriately. Pre service teacher education is that field which prepares teachers before their entrance into the teaching profession. It is the platform where ignorant, unskilful individuals get proper training on teaching skills, absorb adequate knowledge and competency on pedagogy, experience real class room environment through internship program, inculcate right attitude, develop interest that would mould them to become suitable for teaching profession. The role of pedagogical competency in effective science teaching is crucial. However it is found that pedagogical competency of science teacher is low [1]. Pre service teacher education is the foundation of each and every individual practicing teaching profession and it is beyond doubt that the consequence of any wrong pattern of training or fault information would be long lasting, broad and hazardous for whole system of education. In this regard maintaining proper quality in this field is mandatory. Several techniques and strategies have been innovated and applied to make the pre service teacher education more effective. One of the strategies is to use Simulation class before commencing internship program in pre service teacher education at secondary level.

\section{Simulation In Pre Service Teacher Education}

Simulation has been defined as artificial and deliberate representation of real situation. Simulated teaching has been defined as an analogue, a representation of reality but not the reality. It is also described it as controlled representation of reality. Simulation of behaviour means creating artificial in which some kind of behaviour can be evoked which are in real situation.[2].While implementing simulation programme in pre service teacher education a group of students pretend as school students who actually observe the teaching of their friend. . The student teacher who plays the role of school teacher teaches his/her friends and creates real classroom situation. This approach of teacher preparation is one of the functional way to train novice teacher where the pupil teacher uses all the skills of teaching and adopts suitable method of teaching and implement appropriate pedagogy. However reviews of teacher education continually report on a number of key skills that are not well developed by traditional preparation programs. These include: student discipline, motivating students, dealing with individual differences, insufficient and/or inadequate resources, organisation of class 
work, assessing student work, and relationships with parents.[3]. When interviewed, final year pre-service teachers claim that they leave university feeling inadequately prepared for professional practice and often uncertain about what will confront them when they arrive at schools [4],[5]. Schools that employ recent graduates support such claims and further assert that most recent graduates are often unaware of how classroom cultures operate and find it difficult to transfer what they've studied at university into effective classroom practice [6]. Often pre-service teachers do not understand how good classroom practice impacts on student learning[7]. It is claimed that most teacher education courses represent a fragmented view of learning. It is argued that this has enormous potential to hinder the development of pre-service teachers into flexible, progressive practitioners [8]. It is understood that many recent graduates find it difficult to deal with life in the classroom, as they are often unable to retrieve the essential knowledge when they need it most [9],[10],[11],[12]. It is strongly recommended that pre service teachers receive quality classroom based experience supervised by an accredited teacher mentor, the complex decision making processes that teachers typically make in classroom settings. In an ideal world pre-service teachers would have unlimited access to quality classroom episodes that progressively develop their classroom practice. However, the cost of the practicum experience, school needs, school availability and university course requirements place limits on access. Lack of regular access to quality classroom experiences frustrates both teacher educators and pre-service teachers [7]. It is recognised that the initial years of a teacher education program are critical for pre-service teachers to develop fundamental understandings about their future work of teachers. Other ways of providing the sorts of experiences provided during personal experience with classroom based teaching episodes are needed.. It is conceded that school based practical experience often consists of a series of isolated, decontextualised lessons prepared and implemented according to the requirements of the supervising teacher; or at worst it can be an unsupported and disillusioning experience[13],[7]. Experienced claimed that pre-service teacher learning is enhanced when pre-service teachers regularly participate in the complex decision making processes that teachers typically make in classroom settings. In an ideal world pre-service teachers would have unlimited access to quality classroom episodes that progressively develop their classroom practice[14],[15]. However, the cost of the practicum experience, school needs, school availability and university course requirements place limits on access. It is recognised that the initial years of a teacher education program are critical for pre-service teachers to develop fundamental understandings about their future work of teachers. Other ways of providing the sorts of experiences provided during personal experience with classroom based teaching episodes are needed. Therefore it is essential to implement simulation class in pre service teacher education institute to provide them an artificial environment for providing real classroom like experience. It is also important to know effectiveness of simulation class in terms of exposing whether these simulation classes have helped the student teacher in internship program and in which way through teacher educators and student teacher.

\section{Research Question}

What are the impacts of simulation class on pedagogical competency of science teacher during internship program?

\section{Objectives Of The Study}

The objectives of the study are as follows:

- To find out the level of pedagogical competency of student science teacher before internship program

- $\quad$ To find out the level of pedagogical competency of student science teacher after implementing simulation classes during internship program

- To compare the pedagogical competency of science teacher before after simulation classes.

\section{Hypothesis}

The hypothesis of the study is, "There will be no significant difference in the scores of science student teacher before and after simulation classes with respect to their pedagogical competency".

\section{Methodology}

Action Research has been used to conduct the research

\section{Sample}

For the present study 40 B.Ed. students from science method have been taken into consideration studying in Nabakrushna Chudhury College of Teacher Education, Angul. 


\section{Tools}

Following tools have been used to carry out the research study.

7.1 .A self developed five point Observation Schedule for assessing Pedagogical Competency of student teacher. Self developed Observation Schedule is used for assessing pedagogical competency of science teacher at secondary level. This tool is based on five criteria such as i) attitude while teaching in the classroom ii) scientific approach to teach science iii) content knowledge iv) knowledge of teaching methods v) skills of teaching science. Again the author also listed indicators for each criterion for easy observation and recording. So the content validity of the tool is ensured by experts and science teachers. The tool is administered twice on 20 science teachers teaching at secondary level, Odisha. The reliability of the observation tool was estimated by using test-retest method by giving seven days gap. The reliability coefficient was calculated by taking scores of two tests. The reliability coefficient was found to be 0.6 .

7.2 An check list is developed to find out the opinion of students regarding the usefulness of simulation class. It is designed for self assessment of student teacher regarding their pedagogical competency.

7.3 One unstructured interview schedule is utilized to take the opinion of faculty members to explore the effectiveness of simulation class.

\section{Analysis And Interpretation And Findings}

The objective of the study was to find the pedagogical competency of science teacher during internship. By using the self developed observation schedule the pedagogical competency of science student teacher was assessed before and after implementing simulation class.

Table-1 Score Range and Level of Pedagogical Competency

\begin{tabular}{|l|l|l|l|l|}
\hline $\begin{array}{l}\text { Percentage of } \\
\text { score }\end{array}$ & Remark & $\begin{array}{l}\text { Level of } \\
\text { Pedagogical } \\
\text { Competency }\end{array}$ & $\begin{array}{l}\text { Number Student } \\
\text { Teacher Before } \\
\text { Simulation Classes }\end{array}$ & $\begin{array}{l}\text { Number of Student } \\
\text { Teacher After } \\
\text { Simulation Classes } \\
\text { (During Internship } \\
\text { Programme) }\end{array}$ \\
\hline Less than 20 & Very poor & $\begin{array}{l}\text { Low Pedagogical } \\
\text { Competency }\end{array}$ & $23(57.5 \%)$ & $10(25 \%)$ \\
\hline $40-59$ & Good & $\begin{array}{l}\text { Average } \\
\text { Pedagogical } \\
\text { Competency }\end{array}$ & $12(30 \%)$ & $21(52.5 \%)$ \\
\hline $90 \&$ above & Excellent & $\begin{array}{l}\text { High Pedagogical } \\
\text { Competency }\end{array}$ & $5(12.5 \%)$ & $9(22.5 \%)$ \\
\hline Total & & & 40 & 40 \\
\hline
\end{tabular}

The observation schedule was administered among 40 secondary school science student teachers without simulation class. By analyzing the data it is found that high percentages i.e. 57.5\% of teachers have low pedagogical competency (PC), 30\%teachers have average PC and only $12.5 \%$ teachers have high PC level. However after simulation classes by analyzing the data it is found that high percentages i.e. $25 \%$ of teachers have low pedagogical competency (PC), 52.5\% teachers have average PC and only $22.5 \%$ teachers have high PC level. Figure 1 shows the high, average and low level of pedagogical. Competency of sudent science teachers before and after simulation class.

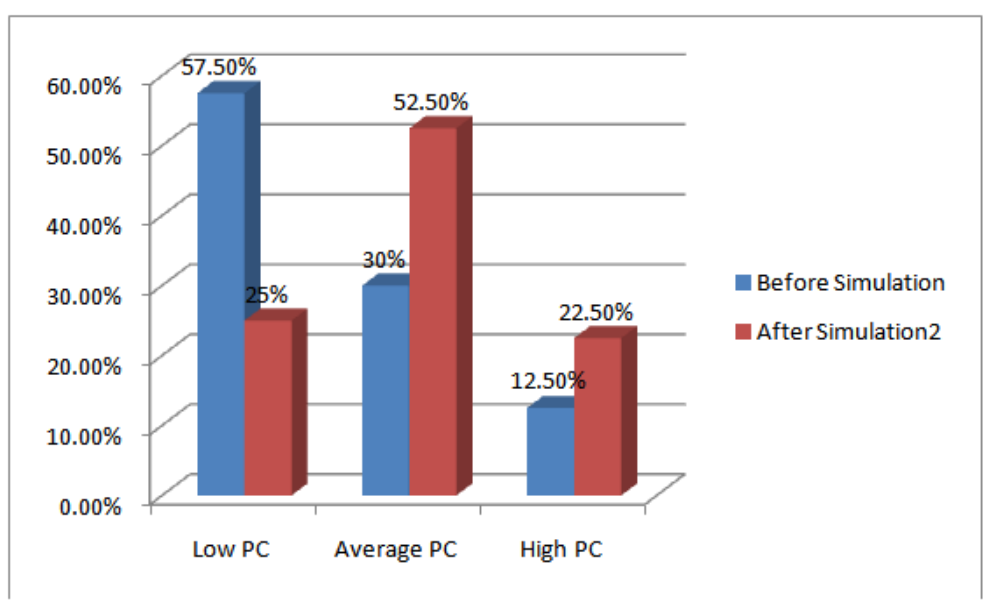

Fig1: Level of Pedagogical Competency of Science Teacher Before and After Simulation Classes 
From the figure it is clear that after simulation classes the percentage of averagely and highly competent teachers increased by $22.5 \%$ and $10 \%$ respectively. However the low competency level decreases by $32.5 \%$. Thus it is evident that after simulation classes the level of pedagogical competency among student science teacher enriched.

Through the self assessed check list also it is found that about $87 \%$ science student teachers agreed that simulation classes helped their pedagogical competency.

Table 2: Table showing t test between scores of pedagogical competency of student science teacher before and

\begin{tabular}{|c|c|c|c|c|c|c|c|c|}
\hline Administration & Mean & Median & Mode & S.D. & $\begin{array}{l}\text { Degree of } \\
\text { freedom }\end{array}$ & t value & $\begin{array}{l}t \text { value at. } 05 \text { level } \\
\text { of Significance }\end{array}$ & Result \\
\hline I & 155.35 & 127 & 120 & 107.10 & 38 & 4.29 & 2.7 & Significant \\
\hline II & 255.125 & 179 & 340 & 112.04 & & & & \\
\hline
\end{tabular}

It is found that the $t$ value between two sets of data is 4.29 which is greater than tabulated value i.e. 2.7 at 0.5 level of significance. So null hypothesis is rejected i.e. There will be no significant difference in the scores of science student teacher before and after simulation classes with respect to their pedagogical competency. And alternative hypothesis i.e. There will be significant difference in the scores of science student teacher before and after simulation classes with respect to their pedagogical competency

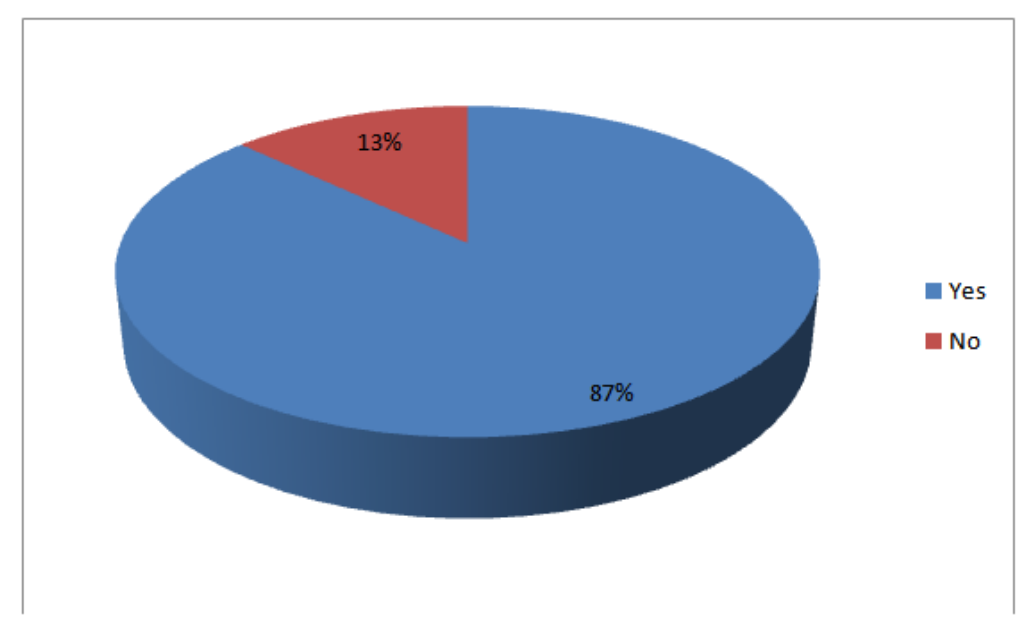

Figure 2: Student Teachers' response regarding effectiveness of Simulation Classes through Check list

An unstructured interview is carried out to fetch the opinion of faculty members regarding effectiveness of simulation classes. It is found that $95 \%$ of faculties have opined that simulation classes are effective tool to enrich the pedagogical competency of student science teachers.

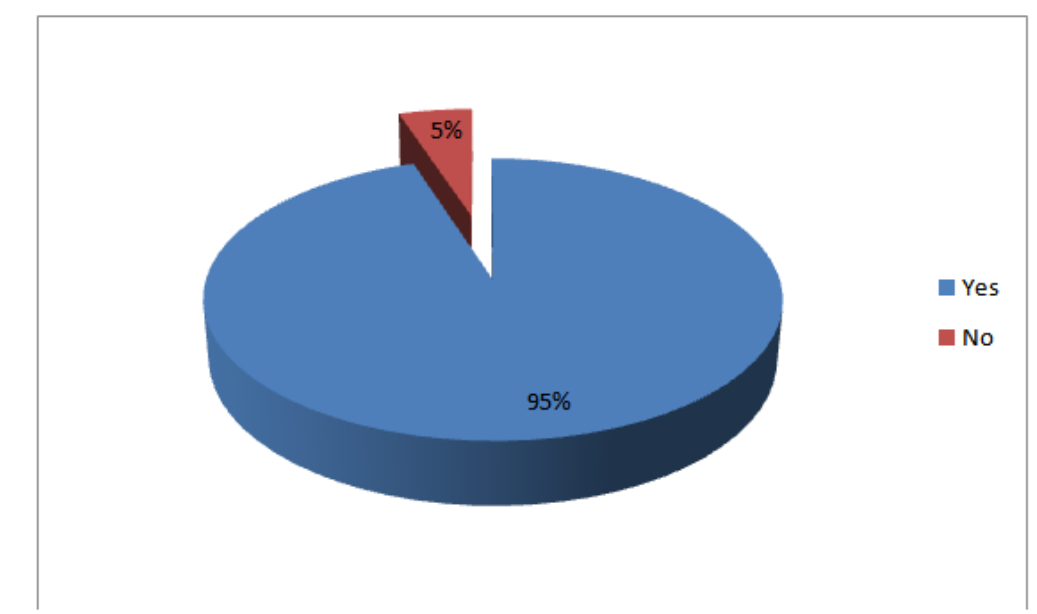

Figure 3: Faculties response regarding effectiveness of Simulation Classes 


\section{Conclusion}

From the research study, by comparing the scores obtained by science student teachers before and after simulation, it is found that there lies significant difference in pedagogical competency of science teachers. It indicates that simulation classes have positive impacts on internship programme. Students become more competent pedagogically to teach science in internship programme due to simulation classes. Their content clarity, competency to plan lesson as well as select appropriate methodology has also improved. Student could able to choose appropriate teaching aids and use them effectively. Further competency to perform skills such as introducing, explaining, illustrating, questioning a lesson in science class has also get elevated. In addition to this student teacher also developed ability to organize activities, demonstrate several experiments in science class. They nurtured competency to create child centred learning science in classroom. Student science teachers are also found to be confident to teach as well with sound body language and possessed appropriate level of competency to expose skill of stimulus variation. However during internship programme many student teachers failed to manage classroom discipline and reported that it is difficult for them. The probable cause behind this may be due to student teachers were acquainted with the nature of artificial classroom situation and virtual secondary school students during simulation classes. Students and faculties also remarked that simulation classes are effective for enrichment of pedagogical competency. Science student teachers remarked that simulation classes have helped them to overcome the fear to face natural class and teach science. They felt simulation classes made them confident. Faculty members also opined that simulation classes have nurtured pedagogical competencies of science student teachers. Hence simulation classes should be made compulsory for each pre service education to maintain the quality and enrich pedagogical competency of student teacher.

\section{Acknowledgement}

I would like to thank the participants involved in this study; I am also thankful to Dr. K.P. Mishra, (Principal) and Mrs. S.N. Lenka, (Reader in Education), Nabakrushna Choudhury College of Teacher Education, Angul for supporting and organizing Simulation schedules during pre internship phase of pre service science teacher education.

[1]. Panda, S.,(2012), Mapping Pedagogical Competency of Secondary School Science Teacher: An Attempt and Analysis, International Educational E-Journal, \{Quarterly\}, ISSN 2277-2456, Volume-I, Issue-IV, July-Aug-Sept 2012

[2]. Sharma, R. 2008. Pedagogics of Education and Critical Pedagogy, International Publishing House, Meerut, India.

[3]. Koetsier, C.P. \& Wubbels, J. T. (1995). Bridging the gap between initial teacher training and teacher induction. Journal of Education for Teaching, 21(3), 333-345.

[4]. Cambourne, B., Kiggins, J. \& Ferry, B. (2003). Replacing traditional lectures, tutorials and exams with a knowledge building community (KBC): A constructivist, problem-based approach to pre-service primary teacher education. English Teaching: Practice and Critique, 2(3), 7-21. http://www.tmc.waikato.ac.nz/english/ETPC/article/pdf/2003v2n3art1.pdf [verified 15 Oct 2004]

[5]. Armour, L. and Booth, E. (1999). Analysis of a questionnaire to primary educators at schools accepting students for the six week extended practicum. Report by Faculty of Education: University of Wollongong..

[6]. MACQT (1998). Teacher preparation for student management: Responses and directions. Report by Ministerial Advisory Council on the Quality of Teaching, October, 1998. Sydney: NSW Department of Education and Training.

[7]. Ramsey, G. (2000). Quality Matters: Revitalising teaching: Critical times, critical choices. Report of the Review of Teacher Education in NSW. Sydney: NSW Department of Education \& Training. http://www.det.nsw.edu.au/teachrev/reports/

[8]. Hoban, G. F., (2002). Teacher Learning for Educational Change.Philadelphia: Open University Press.

[9]. Kervin, L. \& Turbill, J. (2003). Teaching as a craft: Making links between pre-service training and classroom practice.

[10]. English Teaching: Practice and Critique, 2(3), 22-34. [viewed 24 Mar 2004, verified 14 Oct 2004] http://www.tmc. waikato.ac.nz/english/ETPC/detail.lasso?id=48

[11]. Stronge, J. H. (2002). Qualities of Effective Teachers. Alexandria, Virginia: Association for Supervision and Curriculum Development.

[12]. Danielson, C. (1996). Enhancing Professional Practice: A framework for teaching. Alexandria, Virginia: Association for Supervision and Curriculum Development

[13]. Entwhistle, N., Entwhistle A. \& Tait H. (1993). Academic understanding and the contexts to enhance it: A perspective from research on student learning. In T.M. Duffy, J. Lowyck \& D.H. Jonassen (Ed), Design Environments for Constructive Learning. Heidelberg: Springer-Verlag, 331-357.

[14]. Darling-Hammond, L. (1999). Teacher education: Rethinking practice and policy. Unicorn, 25(1), 31-48.

[15]. Groundwater-Smith, S., Deer, C. E, Sharp, H. \& March, P (1996). The practicum as workplace leaning: A multi-modal approach in teacher education. Australian Journal of Teacher Education, 22(2), 21-30.

[16]. Cambourne, B. L. (2000). Conditions For Literacy Learning: Observing literacy learning in elementary classrooms: Nine years of classroom anthropology. The Reading Teacher, 53(6), 512-517. 